\title{
O DIREITO MULTICULTURAL E A REDE DE PROTEÇÃo DOS DIREITOS DA CRIANÇA E DO ADOLESCENTE INDÍGENAS EM DOURADOS (MATO GROSSO DO SUL)
}

\author{
MULTICULTURAL LAW AND THE INDIGENOUS CHILD AND \\ ADOLESCENT'S RIGHTS PROTECTION NETWORK IN DOURADOS \\ (MATO GROSSO DO SUL)
}

\author{
Antônio José Guimarães Brito* \\ Bianca Pereira Faria **
}

\begin{abstract}
RESUMO: O presente artigo visa analisar se a atuação da Rede de Proteção dos Direitos da Criança e do Adolescente de Dourados/MS resguarda as especificidades étnicas dos povos indígenas Guarani e Kaiowá, quando aplica as políticas públicas e os mecanismos de atendimento que visam assegurar a Proteção Integral prevista na Lei ${ }^{\circ}{ }^{8}$ 8.069/90 e na Constituição Federal de 1988. A partir de revisão bibliográfica e análise da legislação pertinente, utilizando-se do método histórico-dedutivo, foi possível verificar as alterações que introduziram a concepção de crianças e adolescentes como sujeitos de direitos, bem como as mudanças que reconheceram a organização social, os costumes, as línguas, as crenças e as tradições dos povos indígenas. Desta maneira, conjugando estes dois aspectos, tem-se que o Estado brasileiro, redefinido como pluriétnico, proporciona a aplicação da legislação pátria, neste caso, o Estatuto da Criança e do Adolescente, de modo a respeitar o multiculturalismo.
\end{abstract}

PALAVRAS-CHAVE: Criança e adolescente indígena. Rede de Proteção dos Direitos da Criança e do Adolescente em Dourados/MS. Estatuto da Criança e do Adolescente.

\begin{abstract}
This article aims at analyzing if the Child and Adolescent's Rights Protection Network's proceedings observe the ethnical specificities of the Guarani and Kaiowá indigenous peoples when applying the public policies and attending mechanisms designated to assure Integral Protection, present on the Law 8.069/90 and on the 1988 Brazilian Republic Constitution. By means of bibliographic review and related laws analysis, employing the historical-deductive method, it was possible to verify the alterations that inaugurated the concept of children and adolescents as subjects of rights, as well as the ones that acknowledged these indigenous peoples' social organization, practices, languages, belief systems and traditions. Hence, taking both aspects, it is understood that the Brazilian State, redefined as pluriethnic, applies the national legislation, in this case, the Brazilian Child and Adolescent Statute, in compliance with multiculturalism.
\end{abstract}

KEYWORDS: Indigenous child and adolescent. Child and Adolescent Right's Protection Network in Dourados/MS. Brazilian Child and Adolescent Statute.

* Doutor em Direito pela Universidade Federal de Santa Catarina (UFSC). Mestre em Direito pela Universidade Federal de Santa Catarina (UFSC). Professor Adjunto da Universidade Federal da Grande Dourados (UFGD), nos cursos de graduação em Direito e Relações Internacionais (FADIR/UFGD) e no Programa de Mestrado em Antropologia - PPGAnt/UFGD. E-mail: antoniobrito@ufgd.edu.br.

**Bacharel em Direito pela Universidade Federal da Grande Dourados (UFGD) e Agente em Indigenismo da Fundação Nacional do Índio em Dourados/MS. E-mail: biancapfaria@hotmail.com. 
Os Guarani e Kaiowá do Mato Grosso do Sul são internacionalmente conhecidos pela dramática situação em que se encontram. Os conflitos fundiários, o confinamento nas reservas, o crescente índice de suicídios, a desnutrição infantil e muitos outros problemas têm sido divulgados nos últimos anos. No entanto, o que está sendo veiculado atualmente, principalmente nas redes sociais, revela situações que já ocorrem há muito tempo, mas que foram historicamente ocultadas pela invisibilidade que sempre marcou esses povos.

Por isso, diante deste cenário de severas violações de direitos humanos e devido à proximidade com o tema proporcionada pelo exercício das atividades como Agente em Indigenismo da Fundação Nacional do Índio em Dourados/ MS, iniciamos a pesquisa no sentido de verificar como vivem as crianças e os adolescentes indígenas dessas etnias e como os operadores dos direitos humanos atuam no sentido de resguardar-lhes as garantias constitucionais fundamentais.

Para tanto, buscaremos conceituar o direito como produto de uma cultura, cuja aplicação deve considerar as peculiaridades dos demais segmentos étnicoculturais que são por ele atingidos. Desta maneira, as disposições legais acerca dos Direitos da Criança e do Adolescente devem ser interpretadas em consonância com os direitos étnicos das comunidades a que ele se destina, como forma de resguardar o Estado Pluriétnico adotado pelo Brasil, em sua Constituição Federal de 1988.

Do mesmo modo, os Direitos da Criança e do Adolescente se adequaram às disposições constitucionais, o que pode ser observado nas diversas alterações que ocorreram desde o Código de Menores (Lei nº 6.679/79), que trazia a ideia de menor em situação irregular, objeto de intervenção do Estado, até o atual Estatuto (Lei $\left.\mathrm{n}^{\circ} 8.069 / 90\right)$, que concebe as crianças e adolescentes como sujeitos de direitos.

No entanto, a efetivação de tais direitos pressupõe uma rede de atendimento constituída pelos órgãos do Poder Público, devidamente articulada e preparada para atuar de maneira eficaz. Por isso, analisaremos a Rede de Garantia dos Direitos das Crianças e dos Adolescentes do município de Dourados/MS, explicitando as funções e atribuições de cada órgão que a compõe.

Partindo para a seara do Direito Indigenista, observaremos que este também passou por intensas mudanças, desde o Estatuto do Índio (Lei n ${ }^{\circ}$ 6.001/73) até a Constituição Federal de 1988, com fortes influências de normas internacionais. Desta maneira, será possível visualizar que o caráter integracionista da política indigenista brasileira deu lugar à concepção do indígena como indivíduo capaz, sujeito de direitos e desvinculado do regime tutelar que sobre ele recaía. 
Em um contexto mais específico, explanaremos acerca dos povos indígenas de Dourados/MS, abordando o modo como o território do sul do Mato Grosso do Sul era ocupado pelos Guarani e Kaiowá e como a expansão agropastoril influiu na criação das reservas pelo Serviço de Proteção ao Índio (SPI). Além disso, analisaremos os reflexos sociais que a vida nessas reservas ocasionou, principalmente devido ao adensamento populacional.

Por fim, explanaremos sobre as dúvidas que pairam sobre a aplicação do Estatuto da Criança e do Adolescente, quando se trata de povos indígenas, bem como acerca da forma em que a rede tem atuado no município de Dourados/MS, especialmente nos casos de destituição do poder familiar, abrigamento nas cidades e reinserção na comunidade.

Esta pesquisa buscará se orientar a partir de referências bibliográficas sobre os temas aqui expostos, aliadas aos casos vivenciados no dia a dia da Coordenação Regional da FUNAI em Dourados/MS e objetivará analisar a realidade da Rede de Garantias dos Direitos da criança e do adolescente indígena de Dourados/ MS, as dificuldades por ela enfrentadas e as possíveis alternativas para dar mais efetividade a esta atuação.

\section{BREVE ESTUDO SOBRE OS DIREITOS DA CRIANÇA E DO ADOLESCENTE NA PERSPECTIVA ÉTNICA ${ }^{1}$}

“O direito não é atemporal e universal, mas é fruto de determinada condição histórica e cultural de uma sociedade" (VILLARES, 2009, p. 18). Sua construção gradual está marcada pela alteração dos valores da sociedade num dado momento histórico, tendo como fontes o costume, a crença popular e a consciência comum do povo (SALGADO, 2006).

Em 1988, redefiniu-se o desenho constitucional brasileiro, reconhecendose a ideia de que o direito produzido pelo Estado não pode ser considerado como único. Consequentemente, reorientaram-se as relações do Estado com os segmentos sociais minoritários e etnicamente marcados (SILVA, 2009).

Isto porque, apesar de "ideologicamente concebido como íntegro territorialmente, de povo miscigenado (negro-branco-índio) e unificado linguisticamente" (VILLARES, 2009, p. 16), a existência de aproximadamente

1 Nas palavras de Maria Manuela Carneiro da Cunha, "traços culturais poderão variar no tempo e no espaço, como de fato variam, sem que isso afete a identidade do grupo. Essa perspectiva está assim em consonância com a que percebe a cultura como algo essencialmente dinâmico e perpetuamente reelaborado. A cultura, portanto, ao invés de ser pressuposto de um grupo étnico, é de certa maneira, produto deste" (CUNHA, 1983, p. 99). 
230 povos indígenas, 653 terras reconhecidas oficialmente e 180 línguas e dialetos indígenas (MEIRA; PANKARARU, 2010) demonstra a pluralidade de culturas e etnias que o Brasil possui.

Esse é o caráter pluriétnico admitido pela nação brasileira e expressamente garantido na Constituição Federal de 1988, em seu art. 215². Assim, diante deste novo padrão de respeito à heterogeneidade, impõe-se a exata compreensão das pautas de conduta que agora orientam os agentes públicos e políticos. Desta maneira, "a atuação do Estado em relação a esses grupos, de modo a garantir seu direito à identidade, pressupõe a compreensão de suas formas de ver e conhecer o mundo" (PEREIRA, 2002, p. 45).

Neste sentido, os direitos da criança e do adolescente devem ser efetivados sob a égide do Estado Pluriétnico, uma vez que existem "diversas imagens de infância, as quais são socialmente interpretadas e reconstruídas no seio dos grupos e dos processos sociais que lhes dão origem" (COELHO, 2007, p. 5).

Assim, complementa Patrice Schuch (2009), a constituição de crianças e adolescentes como sujeitos está profundamente vinculada aos valores socioculturais de cada contexto particular em que estão inseridas. Portanto, ser criança é viver em um mundo com determinadas condições políticas, sociais e culturais, e não apenas estar situado em determinada faixa etária.

Por serem singulares, a infância e a adolescência devem ser respeitadas em suas alteridades, relativizando as etapas da vida ante as especificidades de classe, gênero e etnia. Por isso, quando a normatização do Estatuto da Criança e do Adolescente aborda a divisão etária das crianças e adolescentes, desconsidera outras lógicas culturais de passagem para a vida adulta, como a dos povos indígenas (OLIVEIRA, 2008).

Além da relativização deste aspecto temporal definidor de infância, Assis Costa Oliveira $(2010$, p. 8527) complementa que

a pluralidade das lógicas culturais de concepção do "ser criança" implica na relativização dos conceitos - como brincadeira, educação, trabalho, ato infracional e tratamento desumano, entre outros, recepcionado pela pergunta: como cada etnia indígena os significa?

Portanto, o Direito presente nos códigos legais, construído com base em concepções universais, muitas vezes divergentes das situações específicas

2 Art. 215. O Estado garantirá a todos o pleno exercício dos direitos culturais e acesso às fontes da cultura nacional, e apoiará e incentivará a valorização e a difusão das manifestações culturais.

$\S 1^{\circ}$ - O Estado protegerá as manifestações das culturas populares, indígenas e afro-brasileiras, e das de outros grupos participantes do processo civilizatório nacional (BRASIL, 1988). 
que envolvem a existência de outras lógicas e dinâmicas culturais, deve ser aplicado considerando as diferenças, a fim de preservar o Estado Pluriétnico constitucionalmente previsto.

No próximo tópico, os Direitos das Crianças e dos Adolescentes serão analisados quanto à sua normatização no ordenamento jurídico brasileiro, também tendo como marco a Constituição Federal de 1988.

\section{DO Código de MENORES AO ESTATUTO DA CRIANÇA E DO ADOLESCENTE}

Analisando o contexto histórico que envolve os direitos da criança e do adolescente, pode se verificar as significativas mudanças que ocorreram no ordenamento jurídico brasileiro, desde o Novo Código de Menores, Lei nº 6.679, de 10 de outubro de 1979, até o Estatuto da Criança e do Adolescente (ECA), Lei $\mathrm{n}^{\circ}$ 8.069, de 13 de julho de 1990, inclusive observando-se a intensa influência de normas internacionais. Tal evolução alterou a concepção até então vigente que considerava o "menor" como objeto de intervenção e não como sujeitos de direitos. Além disso, instituiu um avanço nas políticas públicas para infância e adolescência, baseadas na ideia de Proteção Integral trazida pelo ECA.

Segundo Patrice Schuch (2009, p. 121), "na elaboração do Código de Menores de 1979 o alvo das políticas ficou definido como o "menor em situação irregular' - categoria com referências explícitas à ideia de patologia social e à falta de proteção familiar".

Sua aplicação destinava-se àquelas crianças que se adequavam ao estabelecido no art. $2^{\circ}$ do Código de Menores ${ }^{3}$, tipificando-as como em situação irregular, seja pela carência resultante de falhas na conduta da família ou do menor (incisos I ao IV), seja devido a sua conduta antissocial (V e VI).

3 Art. $2^{\circ}$ Para os efeitos deste Código considera-se em situação irregular o menor:

I - privado de condições essenciais à sua subsistência, saúde e instrução obrigatória, ainda que eventualmente, em razão de:

a) falta, ação ou omissão dos pais ou responsável;

b) manifesta impossibilidade dos pais ou responsável para provê-las;

Il - vítima de maus tratos ou castigos imoderados impostos pelos pais ou responsável;

III - em perigo moral, devido a:

a) encontrar-se, de modo habitual, em ambiente contrário aos bons costumes;

b) exploração em atividade contrária aos bons costumes;

IV - privado de representação ou assistência legal, pela falta eventual dos pais ou responsável;

V - Com desvio de conduta, em virtude de grave inadaptação familiar ou comunitária;

VI - autor de infração penal (BRASIL, 1979). 
Deste modo, os representantes estatais se mantinham inoperantes no que concerne à efetivação dos direitos da criança e do adolescente. Neste sentido, acrescenta André Viana Custódio (2009, p. 25):

\begin{abstract}
Os poderes legislativo, executivo e judiciário mantinham-se regularmente omissos, manifestando-se somente quando as crianças assumiam condição de objeto de interesse "jurídico", seja pela prática de infrações, seja pela própria condição de exclusão social que as colocavam em evidência. Neste momento configurava-se a irregularidade, que nunca era das instituições, mas sempre recaía sobre a criança, pela própria previsão ordenada no sistema jurídico ou pela condição de fragilidade que a submetia as imposições adultas, produzindo o paradoxo da reprodução da exclusão integral pela via da inclusão na condição de objeto de repressão.
\end{abstract}

Portanto, Flávia Piovesan (2010) constata que na experiência brasileira, a marca da herança cultural correcional advém da doutrina do "menor em situação irregular". Contudo, a Constituição Brasileira de 1988, a Convenção sobre os Direitos da Criança, da Organização das Nações Unidas e o Estatuto da Criança e do Adolescente introduziram a concepção da criança e do adolescente como verdadeiros sujeitos de direito, em condição peculiar de desenvolvimento.

Os avanços no campo dos direitos e garantias fundamentais é resultado do processo de democratização trazido pela Constituição Federal de 1988, cuja

moderna concepção do constitucionalismo nacional ensejou não só a ratificação de Tratados e Convenções internacionais de proteção dos Direitos Humanos, como a inclusão em seu texto constitucional, de forma irrevogável, de princípios consagrados nos referidos instrumentos internacionais, dando-lhes força de norma de aplicabilidade imediata (ALBERNAZ JUNIOR; FERREIRA, 1998, s.p.).

A Constituição Federal de 1988, no art. $227^{4}$, portanto, proclamou em seu texto a Doutrina da Proteção Integral, abordando a questão da criança como prioridade absoluta e a sua proteção como dever da família, da sociedade e do Estado.

É certo que, ao introduzir este artigo, a Constituição Federal revogou implicitamente a legislação até então vigente, razão pela qual se clamava por um texto infraconstitucional em conformidade com as conquistas da Carta Magna.

Passados dois anos da Constituinte, o legislador promulgou a Lei $\mathbf{n}^{\circ}$ 8.069/90, que instituiu o Estatuto da Criança e do Adolescente (ECA). Para Patrice Schuch (2009, p. 125), no contexto pós-ECA,

4 Art. 227. É dever da família, da sociedade e do à criança e ao adolescente, com absoluta prioridade, o direito à vida, à saúde, à alimentação, à educação, ao lazer, à profissionalização, à cultura, à dignidade, ao respeito, à liberdade e à convivência familiar e comunitária, além de colocá-los a salvo de toda forma de negligência, discriminação, exploração, violência, crueldade e opressão (BRASIL, 1988). 
o alvo das políticas jurídico-estatais deixou de ser definido como o "menor em situação irregular" e passou a ser definido como crianças e adolescentes "sujeitos de direitos", seguindo a tendência da "universalização da infância". As políticas de atendimento foram definidas para aqueles sujeitos às medidas de "proteção especial" (abandono, maus tratos, etc.) e as medidas "sócio-educativas" (cometimento de ato infracional).

Nesse sentido, complementa-se que

a 'justiça como assistência', a classificação 'menor' e o 'paradigma da menoridade' passam a ser absolutamente criticados como repressores, autoritários e discriminatórios, vistos como mecanismos privilegiados de um poder discricionário em relação à infância e juventude (SCHUCH, 2006, p. 67).

Dentro dessa nova concepção, a prioridade absoluta ao direito da criança e do adolescente surge como princípio norteador das novas relações estabelecidas entre o Estado, a sociedade civil, a família, a criança e o adolescente.

\section{CONCEITO E FUNÇÃ̃ DA REDE DE PROTEÇÃ̃o E SUA REALIDADE NA CIDADE DE DOURADOS/MS}

Após análise das alterações mais significativas trazidas pelo Estatuto da Criança e do Adolescente, há de se considerar que "a complexidade de situações vivenciadas pelas crianças e adolescentes exige a articulação da política de atendimento como forma de superar as lacunas, sobreposições e atitudes contraditórias encontradas na ação dos órgãos públicos" (MORA, 1992, p. 241).

Além disso, o próprio Estatuto da Criança e do Adolescente, no art. $86^{5}$, consolida a importância dos conceitos de rede e de sistema, como salienta Fábio Ribas (2011, s.p.):

Para que seja possível alcançar resultados mais significativos nas ações voltadas à garantia dos direitos das crianças e adolescentes, as instituições, serviços e programas dessa área precisam desenvolver capacidades de trabalho em redes. [...] As redes organizacionais e temáticas, orientadas por diretrizes definidas [...] devem atuar de forma integrada e cooperativa para atender populações em determinados espaços geográficos.

Nas palavras de Ana Christina Moreno Maia Barbosa (2002, p. 31), “o termo rede está entendido como um conceito que se propõe compartilhar objetivos e procedimentos, construindo, a todo momento, interações e compromissos através de vínculos horizontais, de interdependência e complementaridade".

5 Art. 86. A política de atendimento dos direitos da criança e do adolescente far-se-á através de um conjunto articulado de ações governamentais e não governamentais, da União, dos estados, do Distrito Federal e dos municípios (BRASIL, 1990). 
Myrian Veras Baptista (2012, s.p.) complementa este conceito ao afirmar que "a articulação dessa rede relacional apoia-se na clareza dos profissionais nela participantes, de que nenhuma de suas instituições pode alcançar seus objetivos sem a contribuição e o alcance de propósitos das outras".

Nesse sentido, o Conselho Nacional dos Direitos da Criança e do Adolescente (CONANDA) criou parâmetros para a institucionalização e fortalecimento do Sistema de Garantias dos Direitos da Criança e do Adolescente. O art. $1^{\circ}$ da Resolução 113/2006 estabelece que:

Art. $1^{\circ}$ - O Sistema de Garantia dos Direitos da Criança e do Adolescente constitui-se na articulação e integração das instâncias públicas governamentais e da sociedade civil, na aplicação de instrumentos normativos e no funcionamento dos mecanismos de promoção, defesa e controle para a efetivação dos direitos humanos da criança e do adolescente, nos níveis Federal, Estadual, Distrital e Municipal (CONANDA, 2006, s.p.).

Assim, tem-se que a efetivação dos direitos preconizados no Estatuto da Criança e do Adolescente depende da atuação articulada de diversos segmentos governamentais e não governamentais nas quatro grandes linhas previstas no art. 87, da Lei $\mathrm{n}^{\circ}$ 8.069/90: políticas sociais básicas, políticas de assistência social, políticas de proteção especial e políticas de garantias de direitos.

Deste modo, ações realizadas isoladamente, sem articulação entre os atores da rede tende a torná-la fragilizada, com sobreposição de atividades e falta de definição quanto ao papel de cada órgão.

Nesse aspecto, a rede de proteção dos direitos da criança e do adolescente que atua no município de Dourados/MS foi mapeada a partir da análise da tramitação documental e dos encaminhamentos de casos, com o objetivo de entender a sua organização, sua finalidade e as atribuições dos órgãos envolvidos no que concerne aos casos das crianças e adolescentes indígenas.

Basicamente, compõem a Rede de Garantia dos Direitos da Criança e do Adolescente, os seguintes órgãos: o Conselho Tutelar, os órgãos municipais de assistência social, a Secretaria Especial de Saúde Indígena - SESAI, a Fundação Nacional do Índio - FUNAI, o Ministério Público Federal - MPF, a Vara da Infância e Juventude, a Promotoria da Infância e Juventude, além de outras entidades da sociedade civil.

O Conselho Tutelar, conforme dispõe o art. 131, da Lei ${ }^{\circ}$ 8.069/90, é órgão permanente e autônomo, não jurisdicional, encarregado pela sociedade de zelar pelo cumprimento dos direitos da criança e do adolescente. Em Dourados/MS, existe um único Conselho Tutelar que atua em todo o município, inclusive dentro da Reserva Indígena. 
Esse ator da rede é chamado a agir sempre que toma conhecimento de violação ou ameaça de violação dos direitos da criança e do adolescente, promovendo uma análise criteriosa para apuração de cada fato, tomando as providências técnico-administrativas para seu esclarecimento. Desta maneira, as ações do Conselho devem provocar os demais integrantes da rede a articularem suas ações, acompanhando o fato até a restituição dos direitos violados (NASCIMENTO et al, 2009).

No que cabe à municipalidade, os órgãos ligados à Secretaria Municipal de Assistência Social são o Centro de Referência de Assistência Social (CRAS) e o Centro de Referência Especializada de Assistência Social (CREAS). O CRAS é responsável pela organização e oferta de serviços da Proteção Social Básica nas áreas de vulnerabilidade e risco social. É dotado de grande capilaridade devido a sua atuação territorializada (MDS a, 2013), tanto que possui uma unidade na Aldeia Bororó, que atende esta aldeia e a Aldeia Jaguapiru. O CREAS, por sua vez, oferta serviços de proteção especial e continuada a famílias e indivíduos em situação de ameaça ou violação de direitos (MDS b, 2013), por meio de uma equipe multiprofissional.

Na esfera federal, a Secretaria Especial de Saúde Indígena-SESAI, vinculada ao Ministério da Saúde, tem como missão principal o exercício da gestão da saúde indígena, no sentido de protegê-la, promovê-la e recuperá-la (MINISTÉRIO DA SAÚDE, 2013). Nos casos das crianças e adolescentes, a SESAI, por meio do Polo Base e sua equipe multidisciplinar, implanta ações preventivas e educativas, além de intervir nos casos de violência, vulnerabilidade e risco nutricional.

Ainda nessa esfera, compõe a Rede de Garantia dos Direitos da Criança e do Adolescente, a Fundação Nacional do Índio - FUNAI, órgão indigenista oficial que, embora não tenha atribuição específica no que se refere às crianças e adolescentes, possui a missão de proteger e promover os direitos dos povos indígenas, garantindo a promoção dos seus direitos sociais, econômicos e culturais, bem como monitorando as ações e serviços de atenção à saúde desses povos.

Nesse aspecto, merece destaque o Programa de Segurança Alimentar e Nutricional que, por meio de parceria entre a FUNAI, o Ministério do Desenvolvimento Social e Combate à Fome e a Companhia Nacional de Abastecimento, distribui cestas de alimentos à população indígena, com o intuito de atender, emergencialmente, famílias que se encontram em situação de insegurança alimentar e nutricional.

Ademais, dentro da estrutura da FUNAI existem as Procuradorias Federais Especializadas, integrantes da Advocacia-Geral da União que, dentre outras 
atribuições, devem atuar na orientação jurídica e na defesa judicial de todos os direitos e interesses coletivos indígenas, entre os quais se incluem os direitos da criança e adolescente, inclusive destituição do poder familiar, guarda e adoção, conforme art. $1^{\circ}$, VI, da Portaria $n^{\circ}$ 839, de 18 de junho de 2010 (AGU, 2010).

O Ministério Público Federal, no contexto da rede, atua na política de garantia de direitos, visto que possui a função institucional de defender judicialmente os direitos e interesses das populações indígenas (art. 129, V, da Constituição Federal), bem como zelar pela observância destes direitos.

Da mesma forma, a Vara da Infância e da Juventude visa garantir direitos, uma vez que permite o acesso ao Poder Judiciário, competindo-lhe as atribuições constantes na legislação especial, especificamente a adoção de medidas de proteção às crianças e adolescentes sob sua jurisdição.

O Ministério Público Estadual, por meio da Promotoria de Justiça da Infância e da Juventude, é parte legítima nas ações cíveis previstas na Lei $\mathbf{n}^{\circ}$ 8.069/90 e, nas ações que não for parte, é obrigado a atuar na defesa dos direitos das crianças e dos adolescentes, sendo que a sua não intervenção acarreta nulidade do feito - artigos 202 e 204, da Lei $n^{\circ} 8.069 / 90$.

Por fim, existe o Conselho Municipal dos Direitos da Criança e do Adolescente (CMDCA), órgão paritário composto por membros da sociedade civil e do Poder Executivo, cuja função é deliberar, formular e controlar as políticas públicas voltadas ao atendimento de crianças e adolescentes.

Após esta análise, passaremos a abordar sobre os Direitos Indigenistas em si, com destaque para as mudanças ocorridas desde o Estatuto do Índio até a promulgação da Constituição Federal de 1988, bem como para a intensa influência dos organismos internacionais na formulação destes direitos.

\section{DIREITOS INDIGENISTAS: DA LEI No 6.001/73 A CONSTITUIÇÃO FEDERAL DE 1988 E OS ORGANISMOS INTERNACIONAIS}

A legislação indigenista se fundamentou basicamente na estigmatização das comunidades indígenas, tratando-as de forma etnocêntrica e sem se importar com o efetivo atendimento às suas necessidades. Os integrantes destas populações deveriam, portanto, adequar-se a um modelo de sociedade imposto, renegando suas identidades em nome de sua inserção à nação brasileira (SOUZA; BARBOSA, 2011).

Foi nesse contexto que o governo federal iniciou a elaboração de uma legislação para os índios, o que só viria a se concretizar em 1973, quando entrou em vigor a Lei ${ }^{\circ}$ 6.001, conhecida como Estatuto do Índio, até então não revogado (ARAÚJO, 2006). 
A legislação indigenista brasileira, portanto, na maneira como foi concebida, fundamentava-se na política integracionista dos povos indígenas, considerados como silvícolas (os que vivem na selva, alheios à sociedade nacional), ao invés de estar atrelada à promoção de seus interesses e garantia de seus direitos.

Logo no seu artigo primeiro, o Estatuto do Índio anuncia seu propósito de "integrá-los progressiva e harmoniosamente à comunhão nacional", contradizendo a parte inicial do artigo que prevê "o propósito de preservar a sua cultura" (SOUZA; BARBOSA, 2011).

Incongruências como essa estão presentes em todo o dispositivo legal que ora tenta proteger os índios e seus valores culturais, ora disciplina o processo de integração do índio à sociedade nacional. Para Ana Valéria Araújo (2006, p. 32), "tratava-se, portanto, de uma lei cujos destinatários eram como "sujeitos em trânsito', portadores, por isso mesmo, de direitos temporários, compatíveis com a sua condição", que perdurariam até sua completa integração à sociedade envolvente.

Aliado a isto, o Estatuto do Índio dispõe ainda sobre a tutela incumbida à União sobre os índios e comunidades não integradas, exercida através do órgão indigenista oficial, a Fundação Nacional do Índio - FUNAI. Em seu art. $8^{\circ}$, considera que "são nulos os atos praticados entre o índio não integrado e qualquer pessoa estranha à comunidade indígena quando não tenha havido assistência do órgão tutelar competente" (BRASIL, 1973).

Mais à frente, no art. $9^{\circ}$, contempla-se a possibilidade da emancipação do indígena ser requerida ao Juiz competente, desde que preenchidos os requisitos nele estabelecidos ${ }^{6}$.

Tem-se, portanto, nas palavras de Manoel Nascimento de Souza e Erivaldo Moreira Barbosa (2011, s.p.),

que o indígena brasileiro, ao nascer, já se encontra sob o regime de tutela, sendo incapaz para os atos da vida civil até que atenda a certos requisitos e torne-se livre deste regime [...]. Tal situação afeta diretamente o efetivo exercício dos direitos indígenas por seus titulares, se revelando como expressão típica do sistema da integração defendido por tal legislação.

${ }^{6}$ Art. $9^{\circ}$ Qualquer índio poderá requerer ao Juiz competente a sua liberação do regime tutelar previsto nesta Lei, investindo-se na plenitude da capacidade civil, desde que preencha os requisitos seguintes:

I - idade mínima de 21 anos;

II - conhecimento da língua portuguesa;

III - habilitação para o exercício de atividade útil, na comunhão nacional;

IV - razoável compreensão dos usos e costumes da comunhão nacional.

Parágrafo único. O Juiz decidirá após instrução sumária, ouvidos o órgão de assistência ao índio e o Ministério Público, transcrita a sentença concessiva no registro civil (BRASIL, 1973). 
Acrescenta Rosane Lacerda (2008), que esta concepção da incapacidade indígena passou a ser vista tanto pela sociedade em geral, quanto pelos agentes dos órgãos públicos, como absolutamente natural, consolidando o estereótipo de que os indígenas eram sem voz e inativos, sempre necessitando serem representados em seus diversos interesses.

No entanto, contrariando a visão que a sociedade em geral lançava sobre o indígena, na década de 1980 - durante o processo constituinte - intensas mobilizações sociais foram organizadas com a finalidade de ampliar o apoio a projetos de lei de interesse indígena.

Nesse momento, destacou-se a atuação, por exemplo, da União das Nações Indígenas - UNI que, à época da formação da Assembleia Nacional Constituinte, "na condição de representante dos povos indígenas, se fez presente tanto nas discussões eleitorais, como, posteriormente, na defesa dos direitos destes na Constituição" (DEPARIS, 2009, p. 143), resultando na inserção de um capítulo específico à proteção dos direitos indígenas na Constituição Federal do Brasil.

Considerada como o marco divisor para a avaliação da situação dos índios no país, a Constituição de 1988 trouxe uma série de inovações no tratamento da questão indígena, pois reconheceu, em seu art. $232^{7}$, direitos permanentes e coletivos, bem como a capacidade processual do índio (ARAÚJO, 2006).

Segundo Araújo (2006, p. 45), "ao afirmar o direito dos índios à diferença, calcado na existência de diferenças culturais, o diploma constitucional, em seu art. $231^{8}$, caput, quebrou o paradigma da integração e da assimilação que até então dominava o nosso ordenamento jurídico".

Assim, complementa Ana Valéria Araújo (2006, p. 45),

ao reconhecer aos povos indígenas direitos coletivos e permanentes, a Constituição abriu um novo horizonte para o país como um todo, criando as bases para o estabelecimento de direito de uma sociedade pluriétnica e multicultural, em que povos continuem a existir como povos que são, independente do grau de contato ou de interação que exerçam com os demais setores da sociedade que os envolve.

Após esta análise, verifica-se que o Estado brasileiro, em sua relação com os povos indígenas, pautou mais pela negação de direitos do que pelo

7 Art. 232. Os índios, suas comunidades e organizações são partes legítimas para ingressar em juízo em defesa de seus direitos e interesses, intervindo o Ministério Público em todos os atos do processo (BRASIL, 1988).

8 Art. 231. São reconhecidos aos índios sua organização social, costumes, línguas, crenças e tradições, e os direitos originários sobre as terras que tradicionalmente ocupam, competindo à União demarcá-las, proteger e fazer respeitar todos os seus bens (ibidem). 
reconhecimento (SOUZA, 2008). Deste modo, não obstante ter havido as inovações constitucionais mencionadas, as diferenças culturais dos povos indígenas ainda são sistematicamente negadas e, desse modo, fadadas à assimilação.

O direito internacional, tal como a legislação pátria, também desenvolveu sua concepção sobre a matéria indígena, num processo direcionado a superar o caráter integracionista que prevalecia nas políticas governamentais.

Isso se evidencia na própria leitura da Convenção nº 169, da Organização Internacional do Trabalho (OIT), que na parte introdutória considera

que a evolução do direito internacional desde 1957 e as mudanças sobrevindas na situação dos povos indígenas e tribais em todas as regiões do mundo fazem com que seja aconselhável adotar novas normas internacionais nesse assunto, a fim de se eliminar a orientação para a assimilação das normas anteriores. (OIT, 2011, p. 12).

Desta maneira, a Convenção $\mathrm{n}^{0} 169$ da OIT veio revisar a Convenção $\mathrm{n}^{\circ}$ 107, com vistas "a tratar dignamente dos direitos coletivos dos povos indígenas, estabelecendo padrões mínimos a serem seguidos pelos Estados e afastando o princípio da assimilação e da aculturação no que diz respeito a esses povos" (ARAÚJO, 2006, p. 59).

No Brasil, esta Convenção foi promulgada em 2004, pelo Decreto $\mathrm{n}^{0}$ 5.051, muito embora vários de seus dispositivos não estejam sendo aplicados integralmente pelo Estado. Para este estudo, merece destaque o art. $2^{\circ}$ da Convenção, que menciona:

Artigo $2^{\circ}$

1. Os governos terão a responsabilidade de desenvolver, com a participação dos povos interessados, uma ação coordenada e sistemática para proteger seus direitos e garantir respeito à sua integridade.

2. Essa ação incluirá medidas para:

a) $[\ldots]$

b) promover a plena realização dos direitos sociais, econômicos e culturais desses povos, respeitando sua identidade social e cultural, seus costumes e tradições e suas instituições. (OIT, 2011, p. 16).

Outro marco relevante para os direitos indígenas na esfera internacional é a Declaração sobre os Direitos dos Povos Indígenas, aprovada pela Organização das Nações Unidas, em 2007, tendo o Brasil como país signatário. Ela "reflete um processo histórico significativo, diante da politização de questões relativas à identidade, à alteridade e à diferença" (BRITO, 2011, p. 85). 
O processo de criação da Declaração outorgou aos representantes indígenas uma participação direta desde 1982 até a finalização do texto da Declaração, em 2006, diferentemente das normas da Convenção $\mathrm{n}^{\circ} 169$ da OIT, que foram criadas sem esta participação (KAINGÁNG, 2008).

“Apesar de não possuir caráter vinculante, trata-se de instrumento legal orientador de políticas internacionais sobre a questão dos direitos indígenas e da relação entre os Estados Nacionais e os povos indígenas" (BRITO, 2011, p. 85).

Nesse aspecto, Azelene Kaingáng (2008, p. 23) ressalta

a importância e a necessidade dos Estados reconhecerem a igualdade de direitos e a proibição da discriminação. A este, segue-se o direito de ser diferente e de viver como tal, bem como o de proteger e manter características e atributos, considerados especiais e próprios desses povos; aspectos que vão desde a cultura até suas instituições sociais.

Portanto, a Declaração também é um instrumento normativo que rompeu com a concepção assimilacionista e com o estereótipo e preconceito contra a identidade e a cultura indígena.

Deste modo, complementa Joênia Wapichana (2008, p. 35):

A utilização de mecanismos internacionais de direitos humanos impulsiona o verdadeiro reconhecimento dos Povos Indígenas como povos, permite um diálogo de iguais para com o Estado e permite fazer com que os Povos Indígenas determinem as prioridades, participem e influenciem nas políticas públicas que lhes dizem respeito como verdadeiros sujeitos de direito.

Logo, verifica-se o avanço do ordenamento jurídico brasileiro e dos dispositivos internacionais no que compete ao atendimento das necessidades e interesses coletivos dos povos indígenas, visando, sobretudo, resguardar a diversidade étnico-cultural brasileira. No entanto, a permanência de um diploma legal eivado pela política assimilacionista (Estatuto do Índio), impede que a atual concepção sobre os direitos indígenas seja amplamente absorvida pela sociedade.

Passada esta abordagem acerca do Direito Indigenista, o próximo tópico analisará os aspectos históricos, culturais e sociais dos povos indígenas Guarani e Kaiowá que residem no município de Dourados/MS.

\section{6}

\section{POVOS INDÍGENAS EM DOURADOS/MS}

Segundo Antônio Jacó Brand (2001, p. 68), “a população Guarani na região da Grande Dourados (MS), [...] em sua grande maioria, corresponde à parcialidade Kaiowá e, em menor número, aos Ñandeva"9. Anteriormente à ocupação

9 Segundo Brand (2001), os Ñandeva se autodenominam Guaranis. 
agropastoril, a população Kaiowá radicava suas parentelas em uma vasta região do sul do estado do Mato Grosso do Sul, onde formavam aldeias denominadas tekohá (PEREIRA, 2006).

Para Levi Marques Pereira (2006), após 1870, com o fim da Guerra entre o Paraguai e a Tríplice Aliança, as terras tradicionalmente ocupadas pelos índios foram gradativamente atingidas pela expansão pastoril e agrícola. Em 1882, “o Governo Federal arrendou a região para a Cia Matte Larangeiras, que inicia a exploração da erva mate em todo o território Kaiowá/Guarani" (BRAND, 2001, p. 68).

Contudo, Alexandra Barbosa da Silva (2009) afirma que a atividade ervateira não afetou o uso que os índios faziam do território, uma vez que não teve o intuito de colonização. Foi somente a partir de 1940, com o encerramento dos contratos de arrendamento que beneficiavam a companhia ervateira, que as comunidades indígenas foram obrigadas a deixar suas aldeias, visto que o governo iniciou uma ação para estimular a compra de terras na região (PEREIRA, 2006). Isto porque o então Presidente da República, Getúlio Vargas, criou a Colônia Agrícola Nacional de Dourados (CAND), que objetivava a migração de colonos de outras regiões do país, para desenvolverem atividades agropastoris na região de Dourados/MS, fato que fazia parte da política de "marcha para o Oeste" (BRAND, 2011).

Antevendo a situação difícil a qual os Guarani e Kaiowá seriam submetidos, o Serviço de Proteção ao Índio (SPI) assegurou a demarcação de espaços destinados ao acolhimento dessa população (BRAND, 2011), denominados reservas indígenas.

Para Alexandra Barbosa da Silva (2009, p. 85), "a condução das pessoas para as reservas deu-se de modo aleatório - resultando que famílias inimigas entre si passassem a ter que conviver nesses espaços delimitados". A esse fato, Antônio Jacó Brand (2001) acrescenta que, além de significar o deslocamento geográfico das aldeias e a correspondente perda de terras, o deslocamento dos indígenas acarretou em inúmeras mudanças nas relações destes com a terra.

Isto porque o território limitado ao qual foram submetidos ocasionou disputas internas por pequenos lotes de terra. Além disso, "o confinamento e a crescente imposição do trabalho assalariado atingiu as bases de sua economia tradicional" (BRAND, 2001, p. 69). Esta, por sua vez, é basicamente fundamentada na agricultura, consideravelmente inviabilizada pela superpopulação e limitação territorial, o que provocou um verdadeiro quadro de genocídio na reserva.

Não obstante a intenção do Serviço de Proteção ao Índio (SPI), “acabaram prevalecendo os interesses dos grandes proprietários particulares, pois apenas nove pequenas reservas foram demarcadas entre 1915 e 1928" (PEREIRA, 2006, p. 71). 
Nesse aspecto, o autor complementa que “o cenário político em Mato Grosso do Sul sempre foi marcado pela hegemonia dos interesses dos grandes proprietários de terras" (PEREIRA, 2006, p. 72).

Dentre as áreas reservadas pelo Serviço de Proteção ao Índio (SPI), temos a demarcação, em 1917, da Reserva Indígena de Dourados, com aproximadamente 3.475 ha (três mil, quatrocentos e setenta e cinco hectares), localizada nos municípios de Dourados/MS e Itaporã/MS (FUNAI, 2013), constituída pelas aldeias denominadas Jaguapiru e Bororó, ocupadas pelas etnias Guarani, Kaiowá e Terena.

Nas palavras de Juliana Grasiéli Bueno Mota (2011, p. 160):

Para compreender minimamente esta reserva, primeiramente é necessário dizer que esta tem a maior densidade populacional por extensão territorial comparado a outras Terras Indígenas do Brasil, estimando haver uma população de 13.020 indivíduos, segundo os dados oficiais da Fundação Nacional de Saúde (2007).

Nota-se, também, que a presença de três sociedades indígenas com modos de organização socioespaciais distintos, sobrepostos em um espaço territorial limitado, torna a Reserva Indígena de Dourados um território precário, com tensionamentos entre um modo de vida e outro (MOTA, 2011). Assim:

\footnotetext{
a redução territorial da reserva contribui para os problemas internos no que concerne ao compartilhamento territorial entre os Guarani, Kaiowá e Terena, pois desconsidera o modo em que cada família extensa e nuclear se organiza através de relações de parentesco e alianças políticas na reserva (MOTA, 2011, p. 201).
}

Para as etnias ocupantes da Reserva, os problemas ali existentes estão diretamente relacionados à falta de espaços disponíveis para a reprodução do correto modo de ser e viver, o que causou inúmeras mudanças no cotidiano e criou desafios para sua organização social que, até hoje, são apontadas como causa dos problemas vivenciados por esta população (BRAND, 1997 apud BRAND, 2011).

Além disso, complementa Antônio Jacó Brand (2011), o confinamento e a superpopulação provocaram o esgotamento dos recursos naturais, precarizando a sustentabilidade dos índios, tornando-os dependentes das políticas governamentais de Segurança Alimentar e Nutricional. Diante de tal fato, estes povos que sempre produziram alimentos em abundância, não conseguem mais prover a sua subsistência e de suas crianças.

Não fosse isto, a condução dos índios às reservas alterou o modo de resolução de conflitos dos Guarani e Kaiowá. "Quando a situação em determinado espaço, por diversas razões, se tornasse inadequada, buscavam outros espaços, dentro 
do mesmo grande território e novas aldeias se constituíam" (BRAND, 2011, p. 123). Agora, confinados em espaços reduzidos, é possível verificar o aumento dos tensionamentos entre os índios residentes na Reserva Indígena de Dourados, que também são agravados pelo consumo de bebidas alcoólicas e outras drogas, dentro da comunidade indígena.

Nesse contexto, são comuns as denúncias de violências contra mulheres, crianças e adolescentes no interior da reserva. As mulheres perderam o grande prestígio que detinham no interior da sociedade, já que não são mais vistas como "produtoras de alimentos". Os filhos, por sua vez, ficam expostos à influência da sociedade de consumo, sem terem condições financeiras para tanto. Somados a isso, o jovem não mais encontra lugar dentro das aldeias e, fora delas, enfrentam grandes preconceitos que dificultam e impedem sua inserção (BRAND, 2011).

Todos esses fatores culminam na dramática situação em que se encontram as populações Guarani e Kaiowá de Mato Grosso do Sul, tendo despertado atenção nacional e internacional, por meio de relatórios que noticiam diversas denúncias de violação aos direitos humanos, especialmente quanto às mulheres, jovens e crianças indígenas.

\section{APLICAÇÃ̃ DO ESTATUTO DA CRIANÇA E DO ADOLESCENTE E A REDE DE PROTEÇÃ̃o À CRIANÇA INDÍGENA EM DOURADOS/MS}

As constantes violações dos direitos das crianças e dos adolescentes indígenas evidenciam a necessidade de tais direitos encontrarem resguardo no ordenamento jurídico brasileiro. Acerca disso, muitas vezes paira dissenso sobre a aplicação da legislação brasileira, no caso o Estatuto da Criança e do Adolescente, quando a mesma entra em conflito com os preceitos culturais das diversas comunidades indígenas existentes no país.

Isso, como já explicado, deriva-se do fato da legislação pátria ser fruto de concepções outras, que não necessariamente comungam com as concepções originárias das culturas e tradições mantidas pelas comunidades indígenas.

No entanto, por meio da Resolução n ${ }^{\circ}$ 91, de 23 de junho de 2003, o Conselho Nacional dos Direitos da Criança e do Adolescente (CONANDA) deliberou acerca da aplicação das disposições constantes do Estatuto da Criança e do Adolescente à família, à comunidade, à sociedade, e especialmente à criança e ao adolescente indígenas registrando que:

Art. $1^{\circ}$ Firmar o entendimento esposado pela Assembleia Ordinária do CONANDA, realizada nos dias 14 e 15 de maio de 2003, no sentido de que se aplicam à família, 
à comunidade, à sociedade, e especialmente à criança e ao adolescente indígenas as disposições constantes da Lei $\mathbf{n}^{\circ}$ 8.069, de 13 de julho de 1990, que dispõe sobre o Estatuto da Criança e do Adolescente observadas as peculiaridades socioculturais das comunidades indígenas (CONANDA, 2003, s.p.).

Desta maneira, a resolução corroborou com o que, posteriormente, foi disposto na Convenção $\mathrm{n}^{0} 169$ da OIT, na medida em que impõe o respeito às peculiaridades socioculturais das comunidades indígenas, na aplicação da legislação nacional vigente. Nesse sentido:

\section{Artigo $8^{\circ}$}

1. Ao aplicar a legislação nacional aos povos interessados deverão ser levados na devida consideração seus costumes ou seu direito consuetudinário.

2. Esses povos deverão ter o direito de conservar seus costumes e instituições próprias, desde que eles não sejam incompatíveis com os direitos fundamentais definidos pelo sistema jurídico nacional nem com os direitos humanos internacionalmente reconhecidos. Sempre que for necessário, deverão ser estabelecidos procedimentos para se solucionar os conflitos que possam surgir na aplicação deste princípio (OIT, 2011, p. 20-21).

No âmbito da legislação específica, as disposições apontadas acima refletiram na publicação da Lei $n^{\circ}$ 12.010/2009 que alterou dispositivos do Estatuto da Criança e do Adolescente, inserindo parágrafos atinentes às crianças indígenas, especificamente quanto à família substitutiva $\left(\operatorname{art.} 28, \S 6^{\circ}\right)^{10}$ e à perda e suspensão do poder familiar (art. 161, $\left.2^{\circ}\right)^{11}$.

Com isso, verifica-se que aos povos indígenas está assegurado o direito material que dispõe sobre sua proteção. Todavia, tais dispositivos carecem de aplicabilidade para alcançarem seus objetivos.

10 Art. 28. A colocação em família substituta far-se-á mediante guarda, tutela ou adoção, independentemente da situação jurídica da criança ou adolescente, nos termos desta Lei.

$\S 6^{\circ}$ Em se tratando de criança ou adolescente indígena ou proveniente de comunidade remanescente de quilombo, é ainda obrigatório:

I - que sejam consideradas e respeitadas sua identidade social e cultural, os seus costumes e tradições, bem como suas instituições, desde que não sejam incompatíveis com os direitos fundamentais reconhecidos por esta Lei e pela Constituição Federal;

II - que a colocação familiar ocorra prioritariamente no seio de sua comunidade ou junto a membros da mesma etnia;

III - a intervenção e oitiva de representantes do órgão federal responsável pela política indigenista, no caso de crianças e adolescentes indígenas, e de antropólogos, perante a equipe interprofissional ou multidisciplinar que irá acompanhar o caso (BRASIL, 1990).

11 Art. $161[\ldots]$

$\S 2^{\circ}$ Em sendo os pais oriundos de comunidades indígenas, é ainda obrigatória a intervenção, junto à equipe profissional ou multidisciplinar referida no $\S 1^{\circ}$ deste artigo, de representantes do órgão federal responsável pela política indigenista, observado o disposto no $§ 6^{\circ}$ do art. 28 desta Lei (ibidem). 
Deste modo, para a efetivação dos direitos das crianças e adolescentes indígenas, é imprescindível o conhecimento das especificidades das sociedades indígenas, a maneira como concebem o conceito de infância e sua inserção na organização social. Entretanto, há um despreparo dos atores da rede para atuar dentro do contexto sociocultural de tais comunidades, visto que buscam proporlhes soluções a partir de sua própria lógica.

Conforme afirma Nascimento et al (2009), as instituições que compõem a rede de atendimento às crianças e adolescentes manifestam posicionamentos opostos no que se refere a alguns pontos de conflito, como por exemplo, "à prática do abrigamento e indígenas nos abrigos da cidade, à destituição do poder familiar das famílias indígenas sobre suas crianças e à adoção de crianças indígenas por não indígenas, inclusive estrangeiros" (NASCIMENTO et al, 2009, p. 145).

Não obstante a existência desses posicionamentos divergentes, pouco se tem feito para proporcionar uma articulação eficaz entre as instituições que compõem a rede de garantia, de modo a se construir uma orientação comum para as ações de atendimento. Além disso, a falta de discussão sobre o assunto tem gerado disputas e desentendimentos quanto às atribuições das próprias instituições (NASCIMENTO et al, 2009).

Nesse sentido, importante destacar a iniciativa da Coordenação Regional da FUNAI em Dourados/MS que, no âmbito do Programa Conjunto de Segurança Alimentar e Nutricional de Mulheres e Crianças Indígenas, executado pela ONU, organizou em 2011 e 2012, os I e II Colóquios Infância e Juventude entre os Kaiowá, Guarani e Terena - O modo de ser, viver e a Rede de Garantia de Direitos (FUNAI, 2012).

Tais eventos objetivaram a construção e implantação de um fluxo de atenção básica integrada para as Redes Municipais de Proteção e Garantia dos direitos à Infância, à Adolescência e a Juventude Kaiowá, Guarani e Terena na Região de Dourados/MS, dentro de um marco da promoção dos direitos humanos. No entanto, o produto final destes encontros ainda não foi disponibilizado, de modo que ainda pairam dúvidas sobre os regimes de atendimento.

Neste ponto, cabe salientar que os Colóquios enfocaram o fluxo de atenção às Redes Municipais. Isso se deve ao fato de que "as municipalidades, com o advento dos processos de descentralização das políticas sociais, têm uma gama de responsabilidades que, na maioria das situações, superam sua capacidade de atenção aos seus munícipes" (SCANDOLA, 2006, p. 7).

Ademais, acrescenta Stela Scandola (2006), embora muitos municípios tenham terras demarcadas em seu território, negam a responsabilidade com o 
povo indígena local. Além disso, o fato do órgão indigenista oficial estar ligado a esfera federal, faz com que outras instituições, municipais e estaduais, afastem de si certas competências e as atribuam exclusivamente àquele órgão que, como já visto, não possui capacidade de gerir todas as ações relacionadas à proteção dos direitos da criança e do adolescente.

Neste ponto, vale ressaltar que o órgão indigenista oficial, a FUNAI, não dispõe de atribuição específica para lidar com o tema aqui debatido, consequentemente, não possui estrutura suficiente para atuar conforme dispõe o art. 28, $\S 6^{\circ}$, III, do Estatuto da Criança e do Adolescente. Por óbvio, essa observação refere-se à Coordenação Regional da FUNAI em Dourados/MS, que não possui em seu quadro funcional, nenhum servidor ligado às áreas de serviço social ou psicologia.

Os apontamentos acima demonstram a dificuldade dos agentes do Estado em identificar e operacionalizar a complexidade de circunstâncias que envolvem a proteção dos direitos da criança e do adolescente indígena. Nesse aspecto, acrescenta Nascimento e Pereira (2011, p. 13):

Além da ausência de formação voltada para compreender as especificidades da organização social Kaiowá, faltam aos agentes da rede referências institucionais, uma vez que as agências que formam a rede de proteção atuam a partir de concepções cristalizadas sobre os modos de ser criança.

Deste modo, destaca-se a dificuldade de atuação da Rede, principalmente no que se refere aos casos de destituição do poder familiar e abrigamento das crianças indígenas na cidade, uma vez que a falta de conhecimento acerca da organização social dos Guarani e Kaiowá dificulta a aplicação do Sistema de Garantias dos Direitos.

Para os Guarani e Kaiowá, a livre circulação de crianças entre as casas das famílias extensas que compõe a mesma família é costumeira, isso porque a família é fundamentada em uma concepção extensiva. Deste modo, as famílias nucleares que compõem a mesma família extensa têm compromissos que se estendem aos cuidados com as crianças, principalmente no caso das famílias com residências próximas (NASCIMENTO et al, 2009).

E ainda, para os Kaiowá, "crescer bem é poder estar com seus parentes, prioritariamente os pertencentes aos núcleos mais concêntricos. Somente este espaço reúne condições ideais para garantir a criança um estado de bem-estar permanente" (CARIAGA, 2012, p. 100).

Todavia, Nascimento e Pereira (2011) explicitam que a condição de reserva na qual os Kaiowá foram inseridos, os impossibilita de gerir suas vidas de forma 
autônoma, o que alterou o sistema interno de circulação de crianças e ocasionou o abandono de mecanismos que antes proporcionavam a resolução dos conflitos. Logo, os Kaiowá tornaram-se cada vez mais suscetíveis às interferências das instituições do Estado.

Para essas instituições, famílias organizadas de outras maneiras que não a estrutura da unidade nuclear são caracterizadas como "desestruturadas" e é nesse sentido que surge outro aspecto preocupante, "a existência de uma espécie de consenso tácito entre parte dos integrantes da rede de proteção à criança, [...] de que pais e mães indígenas não têm condições morais e econômicas para cuidar adequadamente das suas crianças" (NASCIMENTO et al, 2009, p. 145).

É este raciocínio que, muitas vezes, faz com que os atores da rede optem por retirar a criança do seio familiar e abrigá-la em alguma instituição, com o intuito de lhes proporcionarem os cuidados necessários ao seu desenvolvimento. Todavia, o município de Dourados/MS, não possui abrigo destinado unicamente às crianças indígenas, o que pode tornar essa experiência traumática, visto que a atuação da rede é realizada nos mesmos moldes da atuação realizada nos espaços urbanos.

Assim sendo, as crianças abrigadas recebem tratamentos diferenciados dos que recebiam na família de origem. Nas palavras de Nascimento e Pereira (2011, p. 10):

No caso das crianças indígenas abrigadas, elas tendem a receber muitos mimos, alimentação por várias vezes ao dia, motorista que as levam para a escola, etc. Esse é um contraste significativo em relação à cultura indígena Kaiowá, em que as crianças são educadas, na medida do possível, para serem autônomas. Nas famílias Kaiowá, as crianças recebem cuidados e proteção, porém sem excessos de superproteção.

Para estes autores, a retirada da criança indígena do seio familiar e a sua condução para abrigos na cidade causa, no mínimo, um enorme "desconforto cultural", o que sem dúvidas acarreta em dificuldades de reinserção desta criança na sua comunidade de origem (NASCIMENTO; PEREIRA, 2011). Nesse sentido, complementam:

Considerando que em sua experiência pregressa, já foram vítimas de violências ou maus tratos, a experiência no abrigo re-vitimiza essas crianças, forçando-as a se adequarem a um novo código linguístico e cultural. Na situação de abrigo, as crianças indígenas passam por constrangimentos, vendo-se obrigada, por exemplo, a falar e entender uma linguagem que desconhece ou conhece apenas de modo rudimentar (NASCIMENTO; PEREIRA, 2011, p. 11).

No ímpeto de assegurar os direitos destas crianças, a atuação da rede as separa de seus parentes consanguíneos por períodos prolongados ou até mesmo 
definitivos. Isto tende a romper gradativamente os vínculos étnicos entre a criança e a comunidade de origem. Portanto, quanto maior o tempo em que a criança fica institucionalizada, maior será a dificuldade de reinseri-la na comunidade da qual foi retirada.

A adaptação da criança se torna difícil, justamente pelo contraste entre os estilos de vida praticados no abrigo e a forma de viver dos Kaiowá. A isso, somase o fato de que para os Kaiowá, é bastante explícita a diferença de tratamento dispensado aos filhos consanguíneos e aos filhos adotivos. Sobre isso, explicam Nascimento e Pereira (2011, p. 6-7):

Os guaxos, termo utilizado pelos Kaiowá para se referir aos filhos adotivos, podem ser adotados por pessoas nas quais possuem laços biológicos, como avós e tios, por parentes distantes, ou por pessoas que não são parentes, mas que dispõem de maior prestigio social. [...]. Independente da forma de adoção, a tendência é de o guaxo assumir uma posição subalterna na estrutura de prestigio e poder da parentela e da comunidade. No entanto, no caso da criança ter sido adotada pela avó, ela terá um tratamento mais ameno. [...]. Se for adotada por não parentes, será tratada como estranha pelo grupo que a adotou e poderá ter um tratamento mais rigoroso.

À luz do Estatuto da Criança e do Adolescente, este tratamento diferenciado pode ser entendido como discriminação, negligência ou exploração infantil. No entanto, para a comunidade que aqui se refere, a adoção é uma forma de transferir àquela criança os conhecimentos e elementos necessários a sua sociabilidade naquela comunidade.

Nesta conjuntura, retoma-se a questão de que, muitas vezes, a destituição do poder familiar e o consequente abrigamento foram ensejados por uma interpretação equivocada da realidade vivida pelas comunidades indígenas, bem como pela aplicação de conceitos universais que divergem do modo de ser e viver Guarani e Kaiowá, ou ainda, por questões que envolvem conflitos políticos internos da comunidade, não percebidos pelo agente estatal.

Em muitos casos, o Estado interfere visando ampliar o acesso dos indígenas aos direitos amparados legalmente, no entanto, não dialoga com os modelos de cuidado, circulação e parentesco indígena. Assim, as políticas públicas implementadas sobre a "perspectiva intercultural", nem sempre refletem no que os indígenas esperam que seja feito (CARIAGA, 2012).

Portanto, a atuação da Rede de Garantia dos Direitos das Crianças e dos Adolescentes deve se pautar na autonomia e no protagonismo indígena, viabilizando sua participação nos processos decisórios que envolvem seus interesses, permitindo que os indígenas mantenham diálogo constante com os atores sociais e os poderes 
públicos, garantindo que as políticas públicas a eles destinadas sejam efetivadas em consonância com sua própria lógica.

\section{CONSIDERAÇÕES FINAIS}

Ao analisar o Direito como produto de uma cultura, temos que a sua construção baseia-se em concepções do segmento sociocultural que o elaborou, o que muitas vezes não abrange todos os demais segmentos que compõem a sociedade a qual sua aplicação se destina.

Por outro lado, a dinamicidade cultural faz com que o Direito não tenha características fixas e imutáveis, podendo este ser adaptado conforme os anseios da sociedade, a fim de assimilar as mudanças da vida social, buscando solucionar os conflitos que dela emergem.

Isso nos remete a duas consequências/inovações: a primeira, de que a Constituição Federal de 1988 reconheceu o caráter pluriétnico do Estado brasileiro, pautado no respeito à heterogeneidade e na garantia do direito à identidade, rompendo com a visão etnocêntrica que até então vigorava no Brasil; a segunda, de que a legislação brasileira, no que se refere aos Direitos das Crianças e dos Adolescentes e aos Direitos Indigenistas, passou por significativas mudanças em resposta ao clamor das mobilizações sociais.

Quando tratamos dos Direitos da Criança e do Adolescente, temos que o Código de Menores era considerado um “direito tutelar", baseado na doutrina correcional dos menores em situação irregular, objetos de intervenção do Estado. Tal concepção não era condizente com as normas internacionais sobre o assunto, como por exemplo, a Convenção sobre os Direitos da Criança da Organização das Nações Unidas, que trazia a ideia de crianças e adolescentes sujeitos de direitos, em condição peculiar de desenvolvimento.

Logo, o advento da Constituição Federal veio harmonizar as normas do direito interno com relação às normas internacionais, uma vez que passou a reconhecer as crianças e os adolescentes como sujeitos de direitos, cujos interesses devem ser garantidos por lei e exigidos frente à sociedade, à família e ao próprio Estado.

Após, a legislação infraconstitucional acompanhou o exposto na Constituição Federal e ainda dispôs que os direitos e garantias das crianças e dos adolescentes previstos no Estatuto seriam assegurados através da atuação articulada de uma Rede de Garantia de Direitos, composta por órgãos das esferas municipal, estadual e federal. 
De outro lado, quando tratamos dos Direitos Indigenistas, temos o Estatuto do Índio, repleto de disposições que nos remetem à política integracionista/ assimilacionista do Estado brasileiro, instituidor do regime tutelar que submetia os índios à condição de incapazes para o exercício dos atos da vida civil.

No contexto pré-constituinte, os povos indígenas se articularam para reivindicar que a Constituição Federal contemplasse em seu texto, um capítulo específico sobre os Índios. Tal demanda foi atendida, passando a constar nos artigos 231 e 232, disposições acerca do reconhecimento de sua organização social, costumes, línguas, crenças e tradições, bem como legitimidade processual para ingressar em juízo na defesa de seus direitos e interesses.

Após, o Brasil aderiu a normas internacionais que dispuseram acerca do respeito à identidade, à alteridade e à diferença, como a Convenção $\mathbf{n}^{\circ} 169$ da Organização Internacional do Trabalho e a Convenção sobre os Direitos dos Povos Indígenas da Organização das Nações Unidas.

Portanto, a nosso ver, os Direitos da Criança e do Adolescente e os Direitos Indigenistas guardam certa similitude, visto que estão submetidos a estatutos jurídicos específicos, tiveram como marco divisor a Constituição Federal de 1988, que trouxe significativas mudanças no modo como o ordenamento jurídico concebe estes direitos, bem como sofreram alterações influenciadas por normas internacionais.

Logo, temos crianças e adolescentes sujeitos de direitos e indígenas cujas peculiaridades culturais devem ser respeitadas. Deste modo, este estudo buscou conjugar estas duas categorias, para verificar se na proteção dos direitos das crianças e adolescentes indígenas, suas particularidades étnicas são resguardadas pelos operadores dos direitos.

Para tanto, delimitamos como objeto deste estudo, os indígenas das etnias Guarani e Kaiowá, da Reserva Indígena de Dourados/MS, residentes nas Aldeias Jaguapiru e Bororó. Isso porque a condição de reserva que lhes foi imposta acarretou em inúmeros problemas sociais que refletem, principalmente, na violação dos direitos das crianças e adolescentes.

Diante do exposto, primeiramente é importante destacar que pairam dúvidas acerca da aplicação do Estatuto da Criança e do Adolescente quando o mesmo entra em conflito com os preceitos culturais de determinada etnia. No entanto, é patente que tal legislação é aplicável, desde que ressalvadas as diversidades étnicas do povo a que se destina.

Estando o direito material assegurado, as dificuldades se encontram na aplicação do mesmo nos casos concretos. Inicialmente surgem conflitos quanto 
às responsabilidades e atribuições de cada órgão que compõe a Rede de Garantias de Direitos. Neste aspecto, importante destacar que o fato do órgão indigenista oficial, a FUNAI, estar no âmbito do Poder Executivo Federal, faz com que outros órgãos afastem de si, a atribuição de lidar com os índios.

Esse fato demonstra que o resquício da tutela ainda está fortemente presente na maneira como a política indigenista brasileira é concebida por alguns órgãos públicos e por parte da população. Consideramos que isto pode ser atribuído à forma automática de recepção do Estatuto do Índio pela Constituição Federal de 1988, não obstante várias disposições daquele Estatuto sejam contrárias à Carta Magna.

Além disso, outro problema que podemos mencionar é a tendência dos órgãos que compõem a Rede de Garantia dos Direitos em reforçar conceitos que pressupõem uma universalidade da infância, dos sistemas de parentesco e da organização familiar, como se fossem aplicáveis tanto para a sociedade nacional, como para as sociedades indígenas.

Não fosse isto, muitos operadores da Rede não têm formação sobre as especificidades dos índios, o que gera a não compreensão de sua organização social, familiar e política, de maneira que a defesa dos direitos destes povos não contempla os processos próprios de cuidado e educação das crianças no modo de ser e viver Guarani e Kaiowá.

Esse distanciamento da realidade sociocultural dos Guarani e Kaiowá e a aplicação de medidas universais para casos específicos geram as situações discutidas neste trabalho, acerca da destituição do poder familiar, abrigamento de indígenas nas cidades e reinserção dos mesmos na comunidade de origem.

Muitas vezes, as destituições do poder familiar se fundam em circunstâncias que ignoram a livre circulação das crianças Guarani e Kaiowá nas famílias extensas, bem como desconsideram a maneira como esses povos conceituam cuidado, proteção e parentesco, por exemplo.

Prosseguem com a prática do abrigamento nas cidades, sem ao menos ponderar o quanto poderá ser traumática a convivência destas crianças em um meio alheio à sua cultura e o quão difícil será sua readaptação quando houver sua reinserção na comunidade indígena da qual foi retirada.

Portanto, deve ficar sedimentado que as ações políticas permanentes que objetivam a garantia dos direitos dos povos indígenas devem ser realizadas por meio de uma rede articulada, sendo de responsabilidade das três esferas do governo: federal, estadual e municipal. 
Mais do que isso, as ações que visem garantir o acesso das crianças e dos adolescentes aos direitos postulados dependem da implantação de políticas públicas permanentes, que prezem pela interculturalidade, conjugando-se os dispositivos presentes na Constituição Federal, no Estatuto da Criança e do Adolescente, bem como nas convenções internacionais em que o Brasil é signatário, a fim de reverter o dramático quadro de violação dos direitos humanos em que se encontram esses povos.

\section{REFERÊNCIAS}

AGU (Advocacia-Geral da União). Portaria $n^{\circ}$ 839, de 18 de junho de 2010. Disciplina e estabelece critérios para a atuação dos órgãos da Procuradoria-Geral Federal na defesa de direitos indígenas. Diário Oficial da União: Brasília, 21 de junho de 2010. Disponível em: <http://www.agu.gov. $\mathrm{br} / \mathrm{sistemas} / \mathrm{site} /$ PaginasInternas/NormasInternas $/$ AtoDetalhado.aspx?idAto $=254624 \& I D$ SITE $=>$. Acesso em: 16 fev. 2012.

ALBERNAZ JUNIOR, Victor Hugo; FERREIRA, Paulo Roberto Vaz. Convenção sobre os Direitos da Criança - Direitos humanos: construção da liberdade e da igualdade. São Paulo: Centro de Estudos da Procuradoria Geral do Estado, 1998. Disponível em: <http://www.pge. sp.gov.br/centrodeestudos/bibliotecavirtual/direitos/tratadoll.htm>. Acesso em: 8 dez. 2011.

ARAÚJO, Ana Valéria et al. Povos indígenas e a lei dos "brancos": o direito à diferença. Brasília: Ministério da Educação, Secretaria de Educação Continuada, Alfabetização e Diversidade; LACED/Museu Nacional, 2006.

BAPTISTA, Myrian Veras. Algumas reflexões sobre o sistema de garantias de direitos. In: Serviço Social \& Sociedade, São Paulo: v. 109, jan./mar., 2012. Disponível em: < http://www.scielo.br/ scielo.php?pid=S0101-66282012000100010\&script=sci_arttext>. Acesso em: 29 out. 2013.

BARBOSA, Ana Christina Moreno Maia. Redes locais de atenção à criança e ao adolescente. Rio de Janeiro: BNDES, 2002. Disponível em: < http://www.bndes.gov.br/SiteBNDES/export/sites/ default/bndes_pt/Galerias/Arquivos/conhecimento/bndes_social/bndes_social6.pdf $>$. Acesso em: 29 out. 2013.

BRAND, Antônio Jacó. "O bom mesmo é ficar sem capitão": o problema da "administração" das reservas indígenas Kaiowá/Guarani, MS. Tellus, Campo Grande, MS, ano 1, n. 1, p. 67-88, out. 2001.

A criança kaiowá e guarani em contexto de rápidas mudanças - Uma abordagem histórica. In: NASCIMENTO, Adir Casaro (Org.) et al. Criança indígena : diversidade cultural, educação e representações sociais. Campo Grande: Liber Livro, 2011.

BRASIL. Lei $n^{\circ}$ 6.001, de 19 de dezembro de 1973. Dispõe sobre o Estatuto do Índio. Diário Oficial da União: Brasília, 21 de dezembro de 1973. Disponível em: <http://www.planalto.gov. br/ccivil_03/Leis/L6001.htm>. Acesso em: 25 mar. 2012.

. Lei $n^{\circ}$ 6.697, de 10 de outubro de 1979. Institui o Código de Menores. Diário Oficial da União: Brasília, 11 de outubro de 1979. Disponível em: <http://www.planalto.gov.br/ccivil_03/ leis/1970-1979/L6697.htm>. Acesso em: 8 dez. 2011.

Constituição Federal, de 05 de outubro de 1988. Constituição da República Federativa do Brasil de 1988. Diário Oficial da União: Brasília, 05 de outubro de 1988. Disponível em: <http:// www.planalto.gov.br/ccivil_03/constituicao/constituicao.htm>. Acesso em: 8 dez. 2011. 
Lei ${ }^{\circ}$ 8.069, de 13 de julho de 1990. Dispõe sobre o Estatuto da Criança e do Adolescente e dá outras providências. Diário Oficial da União: Brasília, 16 de julho de 1990. Disponível em: <http://www.planalto.gov.br/ccivil_03/leis/L8069.htm>. Acesso em: 8 dez. 2011.

BRITO. Antônio Guimarães. Direitos indígenas nas Nações Unidas. Curitiba: CRV, 2011.

CARIAGA, Diógenes Egídio. As transformações no modo de ser criança entre os Kaiowá em Te’ýikue (1950-2010). 2012. 215p. Dissertação (Mestrado em História). UFGD: Dourados, 2012. COELHO, Ana. Repensar o campo da educação de infância. In: Revista Iberoamericana de Educación, n. 44/3. Organización de Estados Iberoamericanos para la Educación, la Ciencia y la Cultura (OEI): 2007, p. 5. Disponível em: < http://www.rieoei.org/deloslectores/1869Coelho. pdf>. Acesso em: 23 jan. 2013.

CONANDA (Conselho Nacional dos Direitos da Criança e do Adolescente). Resolução $n^{\circ} 113$, de 19 de abril de 2006. Dispõe sobre os parâmetros para a institucionalização e fortalecimento do Sistema de Garantia dos Direitos da Criança e do Adolescente. Disponível em: <http://www. sedh.gov.br/clientes/sedh/sedh/conselho/conanda/resol>. Acesso em: 9 dez. 2011.

Resolução $n^{\circ} 91$, de 23 de junho de 2003. Dispõe sobre a aplicação das disposições constantes do Estatuto da Criança e do Adolescente à família, à comunidade, à sociedade, e especialmente à criança e ao adolescente indígenas. Disponível em: <http://www.sedh.gov.br/ clientes/sedh/sedh/conselho/conanda/resol>. Acesso em: 21 fev. 2013.

CUNHA, Maria Manuela Carneiro. Parecer sobre os critérios de identidade étnica. In: COMISSÃO PRÓ-ÍNDIO. O Índio e a cidadania. São Paulo: Brasiliense, 1983, p. 96-100.

CUSTÓDIO, André Viana. Teoria da Proteção Integral: pressuposto para compreensão do direito da criança e do adolescente. 2008, p. 25. Disponível em: <http://online.unisc.br/seer/index.php/ direito/article/viewFile/657/454>. Acesso em: 8 dez. 2011.

DEPARIS, Sidiclei Roque. A contribuição da União das Nações Indígenas ao movimento indígena brasileiro (1980-1988). Dourados: Nicanor Coelho, 2009.

FUNAI (Fundação Nacional do Índio). Ficha Técnica da TI Dourados. Disponível em: <http:// sti.funai.gov.br:8083/consultas/Fichati.asp?Situacao $=$ Regularizada\&CODTI $=11100>$. Acesso em: 29 jan. 2013.

Texto Base - II Colóquio Regional Crianças Indígena e a Rede de Proteção à Infância, à Adolescência e a Juventude entre os K/G e Terena: o modo de ser, viver e a Rede de Garantia de Direitos. 2012. Disponível em: Coordenação Regional da FUNAI em Dourados/MS. Acesso em: 26 fev. 2013.

KAINGÁNG, Azelene. Natureza e princípios fundamentais da Declaração. In: FRANCO, Fernanda (Org.). Um olhar indígena sobre a Declaração das Nações Unidas. Manaus: COIAB, 2008.

LACERDA, Rosane. Os povos indígenas e a Constituinte - 1987/1988. Brasília: CIMI - Conselho Indigenista Missionário, 2008.

MEIRA, Marcio Augusto Freitas; PANKARARU, Paulo. Direitos humanos e povos indígenas no Brasil. In: VENTURI, Gustavo (Org.). Direitos Humanos: percepções da opinião pública análises de pesquisa nacional. Brasília: Secretaria de Direitos Humanos, 2010.

MINISTÉRIO DA SAÚDE. Conheça a SESAI. Disponível em: < http:/portal.saude.gov.br/ portal/saude/Gestor/area.cfm?id_area=1708>. Acesso em: 11 fev. 2013. 
MDS a (Ministério do Desenvolvimento Social e Combate à Fome). Centro de Referência de Assistência Social. Disponível em: <http://www.mds.gov.br/assistenciasocial/protecaobasica/ cras>. Acesso em: 16 fev. 2013.

MDS b (Ministério do Desenvolvimento Social e Combate à Fome). Centro de Referência Especializado de Assistência Social. Disponível em: < http://www.mds.gov.br/assistenciasocial/ protecaoespecial/creas>. Acesso em: 16 fev. 2013.

MOTA, Juliana Grasiéli Bueno. Territórios e territorialidades Guarani e Kaiowá: da territorialização precária da Reserva Indígena de Dourados à multiterritorialidade. 2011. 406p. Dissertação (Mestrado em Geografia). UFGD: Dourados, 2011.

MORA, Luis de La. Estatuto da Criança e do Adolescente comentado: comentários jurídicos e sociais. Coordenado por Munir Cury, Antônio Fernando do Amaral e Silva e Emílio Garcia Mendez. 2. ed. São Paulo: Malheiros, 1992.

NASCIMENTO, Alexandre Ferreira do et al. Conselhos tutelares. In: ASSIS, Simone Gonçalves de (Org.) et al. Teoria e prática dos conselhos tutelares e conselhos dos direitos da criança e do adolescente. Rio de Janeiro: Fundação Oswaldo Cruz; Educação a Distância da Escola Nacional de Saúde Pública Sergio Arouca, 2009. Disponível em: <http://www.defensoria.sp.gov.br/ dpesp/Repositorio/33/Documentos/Livro\%20Teoria\%20e\%20Pr\%C3\%Altica\%20dos\% 20 Conselhos\%20Tutelares.pdf $>$. Acesso em: 26 fev. 2013.

NASIMENTO, Silvana Jesus do; PEREIRA, Levi Marques. Socialização das crianças indígenas Kaiowá abrigadas e em situação de reinserção familiar. Curitiba: IX Reunião de Antropologia do MERCOSUL, 2011.

OIT (Organização Internacional do Trabalho). Convenção $n^{\circ} 169$ sobre povos indígenas e tribais e Resolução referente à ação da OIT. Brasília: OIT, 2011, v. 1. Disponível em: <http://www. oitbrasil.org.br/sites/default/files/topic/gender/pub/convencao\%20169\%20portugues_web_292. pdf>. Acesso em: 18 nov. 2012.

OLIVEIRA, Assis da Costa. Implicações da doutrina da proteção integral na consideração da criança e do adolescente como pessoas em desenvolvimento. In: CONPEDI. Anais do XVII Encontro Nacional do CONPEDI. Florianópolis: Fundação José Arthur Boiteux, 2008. Disponível em: <http://www.conpedi.org.br/manaus/arquivos/anais/brasilia/05_887.pdf>. Acesso em: 24 jan. 2013.

Crianças indígenas, infância e direitos humanos: novos usos da diversidade cultural. Fortaleza: CONPENDI: 2010, p. 8527. Disponível em: < http://www.conpedi.org.br/manaus/ arquivos/anais/fortaleza/3661.pdf>. Acesso em: 24 jan. 2013.

PEREIRA, Deborah Duprat de Britto. O Estado pluriétnico. In: LIMA, Antônio Carlos de Souza (Org.) et al. Além da tutela: bases para uma nova política indigenista III. Rio de Janeiro: Contra Capa Livraria/LACED, 2002.

PEREIRA, Levi Marques. Assentamentos e formas organizacionais dos Kaiowá atuais: o caso dos “índios de Corredor". Tellus, Campo Grande, MS, ano 6, n. 10, p. 69-81, abr. 2006.

PIOVESAN, Flávia. Apresentação. In: UNGARETTI, Maria América (Org.). Criança e adolescente: direitos, sexualidades e reprodução. São Paulo: ABMP, 2010.

RIBAS, Fabio. Caminhos e desafios para o aprimoramento das redes e sistemas de garantia de direitos. 2011. Disponível em: <http://www.promenino.org.br/Ferramentas/ DireitosdasCriancaseAdolescentes/tabid/77/ConteudoId/c312aaal-d22a-4c8b-b79bdd74ab77025e/Default.aspx>. Acesso em: 9 dez. 2011. 
SALGADO, Karine. História, Direito e razão. Manaus: CONPENDI, 2006. Disponível em: $<$ http://www.conpedi.org.br/manaus/arquivos/anais/manaus/direito_racion_democ_karine_ salgado.pdf $>$. Acesso em: 19 jan. 2013.

SCANDOLA, Stela Márcia Rondina. Crianças dos povos indígenas: apurar o olho e o coração na conquista dos direitos. In: II Seminário Internacional: fronteiras étnico-culturais - fronteiras da exclusão. Campo Grande: NEPPI - Anais do II Seminário Internacional, 2006.

SCHUCH, Patrice. Direitos e Sensibilidades: uma etnografia das práticas de justiça da infância e juventude. In: GROSSI, Miriam Pillar (Org.) et al. Antropologia e direitos humanos 4. Blumenau: Nova Letra, 2006, p. 67.

Práticas de justiça: Antropologia dos modos de governo da infância e Juventude no contexto pós-ECA. Porto Alegre: Editora UFRGS, 2009.

SILVA, Alexandra Barbosa da. Entre a aldeia, a fazenda e a cidade: ocupação e uso do território entre os Guarani de Mato Grosso do Sul. Tellus, Campo Grande, MS, ano 9, n. 16, p. 81-104, jan./ jun. 2009.

SILVA, René Marc da Costa. Estado Democrático de Direito e administração pós-colonial da diferença: o problema da tutela. Prismas: Direito, Políticas Públicas e Mundialização, Brasília, v. 6, n. 1, p. 83-120, jan./jun. 2009. Disponível em: <http://www.publicacoesacademicas.uniceub. br/index.php/prisma/article/view/706/616>. Acesso em: 20 jan. 2013.

SOUZA, Manoel Nascimento de; BARBOSA, Erivaldo Moreira. Direitos indígenas fundamentais e sua tutela na ordem jurídica brasileira. Âmbito Jurídico, Rio Grande, 85, 01/02/2011. Disponível em: <http://www.ambito-juridico.com.br/site/index.php?n_link=revista_artigos_ leitura\&artigo_id=8978>. Acesso em: 25 mar. 2012.

SOUZA, Estella Libardi de. Povos indígenas e o Direito à diferença: do colonialismo jurídico à pluralidade de direitos. 2008. Disponível em: <http://www.nepe.ufsc.br/controle/artigos/ artigo74.pdf $>$. Acesso em: 4 dez. 2012.

VILLARES, Luiz Fernando. Direito e povos indígenas. Curitiba: Juruá, 2009.

WAPICHANA, Joênia. A implementação dos instrumentos internacionais: desafios e fortalecimento dos povos indígenas. In: FRANCO, Fernanda (Org.). Um olhar indígena sobre a Declaração das Naç̃̃es Unidas. Manaus: COIAB, 2008. 